Old Dominion University

ODU Digital Commons

Biological Sciences Faculty Publications

Biological Sciences

2008

Population Ecology of the Golden Mouse

Robert K. Rose

Follow this and additional works at: https://digitalcommons.odu.edu/biology_fac_pubs

Part of the Biology Commons, Population Biology Commons, and the Zoology Commons 


\title{
Population Ecology of the Golden Mouse
}

\author{
ROBERT K. Rose
}

The golden mouse has low variability in niche configuration, occurs in low abundance even at its optimal site, and is highly susceptible to influence by external or successional habitat alteration. (Dueser and Shugart 1979:115)

An understanding of the population dynamics of a species requires knowledge of the major life-history parameters of a population, including age at maturity, distribution of age classes, and lifetime reproductive contribution of the sexes, sex ratio, length of the breeding season, mean litter size, rates of growth and survival, and life span. Because few long-term studies have been conducted with Ochrotomys nuttalli as the focal species of investigation, only fragmentary information is available for many population parameters. As importantly, densities of golden mice often are low, making them difficult to evaluate statistically. Little has been published on age at maturity for golden mice, lifetime reproductive success, or the distribution of age classes in nature. Nevertheless, even early studies provide some useful information focusing on the natural history of this species (e.g., Linzey 1968, McCarley 1958). In this chapter, I summarize studies in which information on one or more parameter(s) is presented, standardize the results as much as possible, and attempt to uncover patterns for populations in one region (e.g., Kentucky, Illinois, Tennessee) to compare with populations from another region (e.g., Florida, Georgia, Texas).

\section{Breeding Season}

Reproduction is crucial to sustain any population, and the potential for population increase depends on sex ratio, mating system, age structure, and reproductive behaviors. Additionally, physical factors of the environment must provide resources such as nesting materials, food to support pregnancy and lactation, and a range of favorable temperatures, among others. In north temperate environments, small mammals have a seasonal duration of a few months in which a large proportion of adults is breeding, followed by a nonbreeding season (usually the winter). However, the southeastern 
United States, in which the golden mouse is distributed, has locations such as peninsular Florida and the Gulf Coast in which winter weather scarcely exists compared to the northern parts of the distribution in southern Illinois or montane locations in Kentucky, Tennessee, and North Carolina. The golden mouse has adapted to the varied environments in different regions by showing the usual spring-autumn breeding season in most locations. In some years and locations, however, southern populations breed during the winter months and avoid breeding during some summer months (e.g., McCarley 1958, Pearson 1953). Thus, golden mice show the same plasticity in their breeding patterns as is seen with the placement of their nests, usually arboreal but sometimes underground (see Chapter 9 of this volume).

The length of the breeding season and other reproductive details are most accurately determined by necropsying a sample of males and females each month. Such samples reveal the proportions of fertile males and pregnant females, embryo counts (= litter sizes), as well as the body masses and lengths (surrogates for age) of the breeders and nonbreeders. Because such thorough year-long studies have not been published for any population of $O$. nuttalli, other and more fragmentary information is used, such as litters born in traps or captivity, backdating to determine the time of birth of half-grown young in nest boxes or traps, embryos counted during necropsy, or the changing reproductive indices of animals captured and released over the course of a year.

In the Smoky Mountains of Tennessee at elevations of 1837-2722 ft (560-830 m), the breeding season extends from mid-March to early October (Linzey 1968). Peaks of breeding are in late spring and early autumn, as determined by the appearance of juveniles in the trappable population, the presence of embryos and sperm in necropsied adults, and from litters born in captivity. A breeding season of similar length is reported for northern Kentucky, based on the presence of preg nant females (Goodpaster and Hoffmeister 1954).

By contrast, the breeding season often differs in southern locations. For example, Ivey (1949), in eastern Florida, found a female with suckling young and four embryos on 3 November, a female with young about 1.5 months old on 21 December, and a female with young about 1 week old on 21 December. This information indicates breeding during October to December, and perhaps longer in the winter.

Pearson (1953) found peak density in the January-May period in central Florida, suggestive that a population increase via reproduction was occurring during early winter. Also in central Florida, Layne (1960) recorded one litter born in January and four litters born in July, pregnant and lactating females in July, September, and November, and a female with newborn young in a nest on 2 March. Thus, Layne suggested an 8- or 9-month breeding season. In a population study conducted in eastern Texas, McCarley (1958) reported that in January and February, most mature mice were in breeding condition, and winter breeding is also supported by the appearance of juveniles and by the attainment of the highest population densities during the winter months. McCarley (1958) stated that unlike northern populations, southern populations of golden mice breed during the winter. These studies of southern populations of golden mice support his contention. 


\section{Litter Size}

Litter size is approximately equivalent to embryo counts, assuming that all embryos survive until parturition. Both kinds of information are useful in determining when breeding starts and ends, and potential population increase. Using all previous information on litter size for golden mice in Florida, Layne (1960) calculated a mean litter size of 2.7 with a modal value of 2 , not different from what Goodpaster and Hoffmeister (1954) and McCarley (1958) reported for Kentucky and Texas populations, respectively. In an intensive evaluation of litter size for this species, Linzey (1968) reported a mean litter size of 2.65 for 85 litters from Tennessee, with mean spring litters smaller (2.4) than those born in September to November (3.1). Blus (1966a) summarized published information on embryo counts and litter sizes and concluded that mean litter size (3.11 \pm 0.10$)$ in northern populations (Illinois, Kentucky, North Carolina, and Tennessee) was significantly greater $(p<0.001)$ than that $(2.47 \pm 0.11)$ of southern populations (Georgia, Florida, and Texas). Thus, golden mice seemingly follow the pattern of many other species of small mammals with regard to litter size; northern populations have larger mean litter sizes than southern populations (Lord 1960).

\section{Growth and Development}

Like many species of small mammals, golden mice have a brief gestation period, 25-26 days (Linzey and Linzey 1967a), followed by a period of nursing and development in the nest. The male plays no observed role in the rearing of young. Newborn golden mice are naked, blind, and helpless, but their rate of growth and development is rapid, so that independence (weaning) is achieved by 3 weeks of age and sexual maturity follows within a few weeks. Spring-born animals breed during the year of their birth, but autumn-born ones might not, especially in more northern populations. The dynamics of this progression to entry into the breeding population remain to be explored for southern populations, which breed in winter. Newborns weigh, 2.4-2.6 g, but their rate of growth is 12.6 percent per day for the first week (Layne 1960), by which time they weigh about $5 \mathrm{~g}$ (Figure 3.1). Growth rate slows thereafter, but at 14 days the young weigh $7.5 \mathrm{~g}$ and at 3 weeks they weigh $10.5 \mathrm{~g}$, approximately half of the adult weight (Linzey and Linzey 1967a).

Physical development occurs in a predictable manner. By day 2, hairs on the back are darkening and extending to the tail, and by day 3, the sutures of the skull have closed (Layne 1960). By day 4, young are able to right themselves easily and are becoming more coordinated in their movements. By day 6, littermates were considered "agile" (Wallace 1969), and their lower incisors erupt (Linzey and Linzey 1967a). Upper incisors erupt a day later on average, and soon the adult proportion of the lower incisor, being twice the length of the upper, is achieved. Eyes open between days 11 and 14 (mean of 12.7 days [Linzey and 


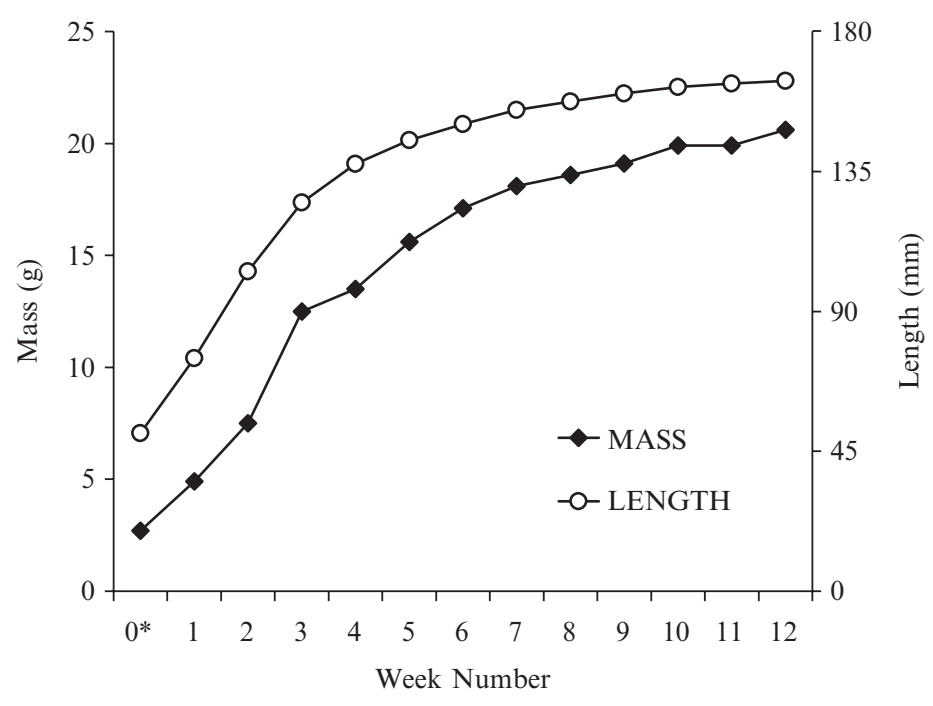

FIGURE 3.1. Growth trajectories of body mass and total length for golden mice for the first 12 weeks of life, based on the laboratory study of Linzey and Linzey (1967a). The asterisk (*) represents the measurements at birth.

Linzey 1967a]), after which the young move about freely (deRageot 1964). The juvenile pelage is fully developed by day 14 (Layne 1960). By day 15, squeaking gives way to chattering, nursing is infrequent, and adult eye shape is attained (Wallace 1969). Some young are weaned at day 17 or 18 , most by day 21 , and all by day 24 (Linzey and Linzey 1967a, Wallace 1969). The postjuvenile molt (leading to adult pelage) starts at week 4 or 5 and usually is completed in 10-14 days (Layne 1960). At this time, youngsters weigh about $19 \mathrm{~g}$, or nearly adult size (Linzey and Linzey 1967a). Young females become fertile and typically enter the breeding population earlier than males.

Spring-born litters gained weight faster than autumn-born litters, and although their linear body measurements were reversed, these differences were slight (Linzey and Linzey 1967a). Layne (1960) concluded that developing young golden mice are superior in many ways to those of syntopic Peromyscus species; they are relatively larger at birth, develop more rapidly, and acquire adaptive behaviors sooner.

Because females suspend molting during pregnancy, an indication of seasonal breeding sometimes can be gleaned from detailed molting information. For example, Linzey and Linzey (1967b) collected 10 golden mice between 12 and 17 December in the Smoky Mountains of Tennessee, of which 6 were molting and 4 already were in winter pelage, indicating that breeding had just ended. By contrast, all wild golden mice observed between 26 March and 1 April were still in winter pelage but had molted by 15 June; this observation indicates that litters likely were born into this population later in April. 


\section{Density}

Population density - the number of individuals per unit area-depends on the rate at which animals enter the population through recruitment by both reproduction and immigration and the rate at which animals disappear, via either emigration or death. Increases in density usually coincide with the entry of young into the population, but little is known about the role of immigrants in contributing to density or of the site fidelity or dispersal of young golden mice. Even less is known about gross mortality (i.e., losses via death or emigration). Density is also a measure of the health and vigor of a population; high densities suggest successful and probably persisting populations as well as quality habitat, whereas low densities more likely indicate newly established or nearly extirpated populations and perhaps marginal habitat. The presence of potentially competing arboreal species, usually in the genus Peromyscus, also often is considered when evaluating density of golden mice. Because golden mice often have patchy distributions, the high variability in estimates of density among geographic populations (Table 3.1) is due in part to whether investigators establish their study grids in optimal habitat for golden mice, or at random within a large homogeneous study area, or the season or duration of the study.

The best estimates of population density are obtained when measured grids are used to study a population using capture-mark-release (CMR) methods over a period of months and years. Few such studies have been published for golden mice. More often, the studies using CMR methods last one summer or parts of two seasons. In addition, instantaneous estimates of population density can be determined when intensive grid trapping, whether with live traps or snap traps, is concentrated within such a brief period as to reduce the confounding effects of birth and death. In such instances, I have used the inclusive boundary strip method (Stickel 1954) to determine the effective area of trapping. This method adds a perimeter of half the trap interval to the enclosed area of the grid. Thus, if the grid is $10 \times 10$ with $10-\mathrm{m}$ intervals, I have added a 5-m boundary strip to the perimeter in determining the effective area of trapping, which, in this example, is 1.0 ha.

Most studies of golden mice have been conducted in deciduous floodplain or mesic upland forests (e.g., Linzey 1968, McCarley 1958, Schmid-Holmes and Drickamer 2001), but sometimes populations have been studied in pine forests or even pine plantations (Mengak and Guynn 2003, Perry and Thill 2005). Whatever the forest type, dense thickets with tangles of vines seem to be required, as noted throughout this volume. The golden mouse is arboreal but spends a variable (and largely unknown) percentage of time on the ground. One or more other arboreal small mammal(s), usually in the genus Peromyscus, is syntopic (live in the same forest community as the golden mouse); all are primarily nocturnal.

Linzey (1968) conducted one of the longest field studies of golden mice using CMR methods. He trapped from June 1964 to August 1966 in the Great Smoky Mountains (Tennessee) National Park and reported a maximum density of 1.5 residents/ha in September 1964 and a low density of 0.1 residents/ha in 


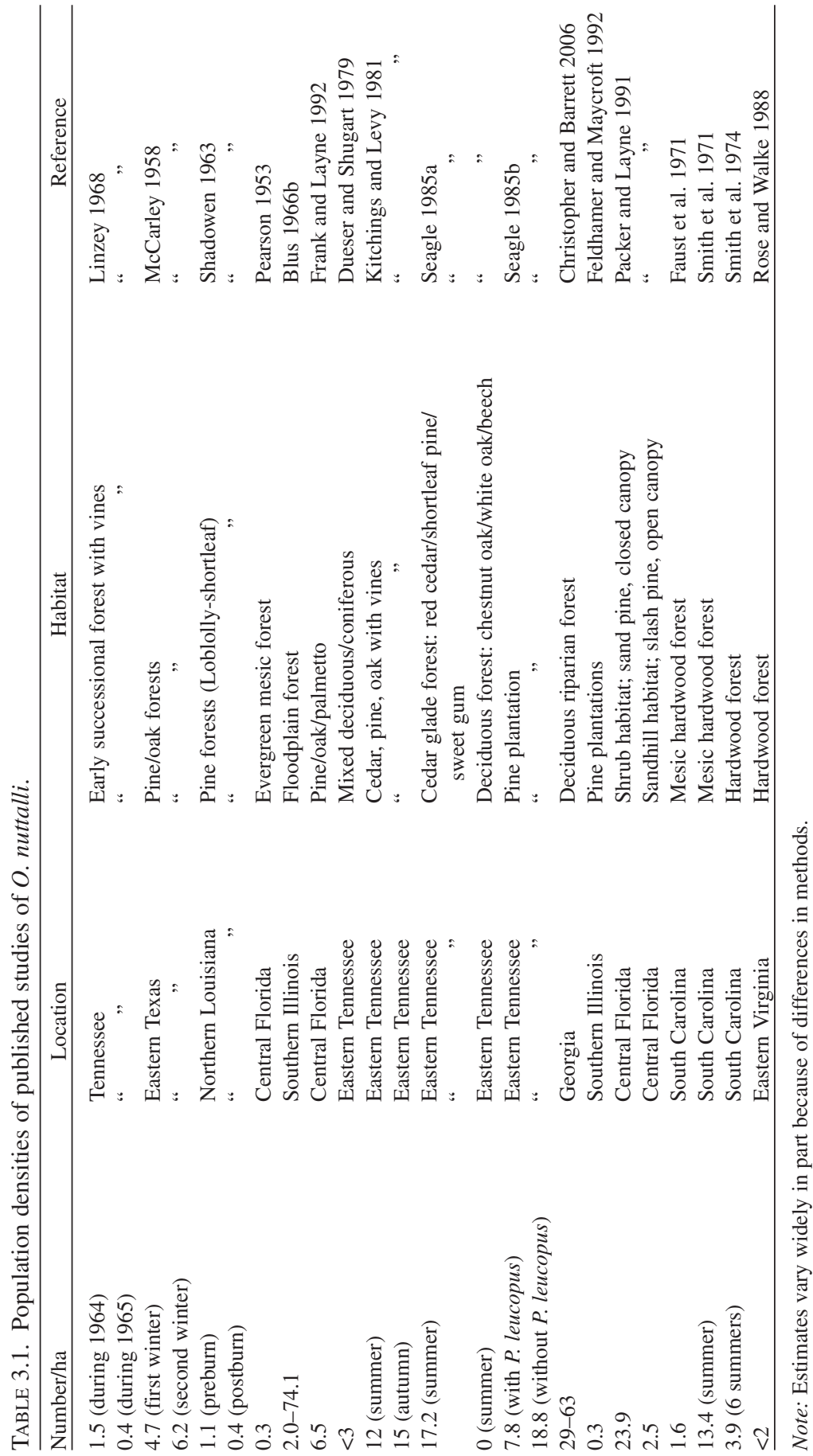


September 1965, a year of reproductive failure (Table 3.1). McCarley (1958), who used a combination of live traps and nest boxes in a 29-month study of golden mouse populations of two large floodplain grids and one large upland (pine/oak) grid in eastern Texas, recorded the highest densities at the end of winter, (4.7 residents/ha in the winter of 1955-1956 and, 6.2 residents/ha in 1956-1957) on one plot, with lesser densities on the other two plots. The period of peak density was January to May, coinciding with the appearance of young during the winter breeding season.

Shadowen (1963) live-trapped $O$. nuttalli and the cotton mouse (P. gossypinus) for 28 months on two large grids in loblolly (Pinus taeda) and shortleaf (Pinus echinata) pine forests in northern Louisiana. The highest densities were 1.1 residents/ha for golden mice and 0.5 residents/ha for cotton mice. Part way through the study, one of the areas was burned and the responses of the species were compared. After the burn, the population of golden mice declined by 65 percent, whereas that of the cotton mouse increased by 155 percent. This change in proportions, reflecting the loss of habitat structure after the fire, was highly significant $\left(\chi^{2}=149.14,3 d f, p<0.001\right)$.

Pearson (1953), using CMR methods in a 1-year study on a 3.64-ha site dominated by evergreen mesic forest in central Florida, caught 18 golden mice and 89 cotton mice (1:5 ratio). The highest density ( 0.3 residents/ha) of golden mice was seen in May at the end of the breeding season. By contrast, the cotton mice had a peak density (1.4 residents/ha) in October. He suggested that golden mice are reluctant to enter traps, unlike most species of Peromyscus. However, once individual golden mice were trapped, they entered traps (four recaptures/animal) as readily as cotton mice (three recaptures/animal).

In another year-long live trapping study, this one on five plots in southern Illinois, Blus (1966b) reported that most densities were less than 1 resident/ha (Table 3.1). However, on one grid in January, he caught 30 animals per acre or 74.1 residents per hectare (Table 3.1). Frank and Layne (1992) used June-September and January-March live trapping on a 2.8-ha grid to determine similar densities (6.5 residents/ha) in summer and winter populations of golden mice in slash pine (P. elliottii)/turkey oak (Quercus laevis)/saw palmetto (Serenoa repens) habitat in central Florida. O. nuttalli outnumbered P. gossypinus 17:6 in summer, but in winter live trappingthe approximate 3:1 ratios were reversed, with cotton mice outnumbering golden mice 51:17.

Kitchings and Levy (1981), who used two 10-day periods of grid trapping in summer and a longer period in autumn in a forest at the Oak Ridge National Environmental Research Park (ORNERP) in eastern Tennessee, also found that seasonal densities of golden mice were more constant than those of the syntopic species of Peromyscus. Densities of Ochrotomys were 12 residents/ha in summer and 15 residents/ha in autumn, whereas those of $P$. leucopus were 15.6 residents/ha in summer and 37.5 residents/ha in autumn. These last two studies perhaps indicate a greater degree of intrinsic population regulation for golden mice than for either Peromyscus species. 
Dueser and Shugart (1979:115), who measured habitat variables to examine niche pattern in a mixed deciduous/coniferous forest at ORNERP, noted that Ochrotomys occupies a position apart from other small mammals, "has low variability in niche configuration, occurs in low abundance even at its optimal site, and is highly susceptible to influence by external or successional habitat alteration." Thus, even in prime habitat, densities often were low. They caught less than 3 residents/ha in trapping conducted during 4 summer months.

In a live trapping study conducted at ORNERP during the summer, Seagle (1985a) recorded a density of 17.2 golden mice/ha (Table 3.1) and 25.0 whitefooted mice ( $P$. leucopus)/ha on a grid in a cedar glade. However, in deciduous forest, he captured no golden mice and 35.9 P. leucopus/ha.

The preceding summer, Seagle (1985b) had studied syntopic O. nuttalli and P. leucopus in a loblolly pine plantation at ORNERP. Using a pair of 1.6-ac (0.64-ha) plots and Sherman live traps, he marked animals for 6 weeks, then removed the P. leucopus from one plot, testing for density compensation by Ochrotomys. Densities of golden mice did increase in the absence of P. leucopus, from 7.8 residents/ha to 18.8 residents/ha, primarily by immigration of animals during the last 7 weeks of trapping. During this interval, densities of golden mice on the control grid decreased from 15.6 to 10.9 resients/ha.

In another study in which the density response by golden mice to the removal of a potentially competing Peromyscus species was examined, Christopher and Barrett (2006), after making density determinations, removed P. leucopus but not other species from 0.21-ha experimental plots in Georgia floodplain and upland deciduous forests. Before removal, the mean abundance of P. leucopus was 25 individuals per grid and the mean maximum abundance of $O$. nuttalli was 15 per grid. Although densities of Ochrotomys did not increase significantly in the absence of $P$. leucopus, they were exceedingly high, from 63 to 92 residents/ha on the multiple treatment and control plots. The authors set traps at ground level and also at 1.5 and $4.5 \mathrm{~m}$ above ground. Golden mice used all elevations equally in the presence of $P$. leucopus, but after the white-footed mice had been removed, golden mice used the 4.5-m traps less and the other two elevations equally. Thus, despite no density compensatory response, golden mice altered activity somewhat, becoming less arboreal in the absence of P. leucopus.

While livetrapping during the summer on 1.6-ac (0.64-ha) grids in 21 pine plantations in southern Illinois, Feldhamer and Maycroft (1992) caught 45 O. nuttalli on 13 sites; white-footed mice were always present $(n=96)$ on the same sites. The density of golden mice was 0.3 residents/ha and that of white-footed mice was slightly more than twice that value. Five other sites had only P. leucopus and three sites had neither species. In a study in which golden mice were sought in 18 forested sites in 15 counties in southern Illinois, Feldhamer and Paine (1987) captured $38 O$. nuttalli and 370 P. leucopus. The latter species was 10 times more abundant on these sites.

Packer and Layne (1991), using live traps during January-April, reported densities of 17.6 golden mice/ha in dense scrub habitat but less than 2.0 golden mice/ha in the more open sandhill habitat in central Florida. In scrub habitat, the 67 golden 
mice were more than double all other species, including cotton mice (25), old-field mice (P. polionotus) (0), Florida mice (Podomys [formerly Peromyscus] floridanus) (2), and hispid cotton rats (Sigmodon hispidus) (1). By contrast, on the sandhill habitat, the 7 golden mice comprised 5 percent of total individuals, which included 30 P. gossypinus, 24 P. polionotus, 61 Podomys floridanus, and 13 S. hispidus.

During 63 consecutive days of mid-summer live trapping on a 16.4-ha grid in lowland mesic hardwood forest at the Savanna River Ecology Laboratory (SREL) near Aiken, South Carolina, Faust et al. (1971) recorded densities of acre (1.6/ha) for golden mice and acre (2.7/ha) for cotton mice. In another study conducted at SREL, Smith et al. (1971) used snap traps in a lowland mesic hardwood forest to determine population densities of small mammals. Initially during 18 consecutive days of trapping on the grid, and later by trapping on assessment lines radiating from the grid, they captured 87 golden mice and 56 cotton mice (and other small mammal species), for density estimates of 13.4 /ha for golden mice and 8.4 /ha for cotton mice. This is another example in which golden mice were numerically dominant to another arboreal rodent of similar body mass and life history.

In yet another study at SREL, this one conducted on a large grid in mature cove hardwood forest (Smith et al. 1974), the average number of golden mice (24.7 \pm $5.3)$ exceeded that of cotton mice $(21.2 \pm 4.4)$. Converted to density, the mean number of golden mice was $3.9 /$ ha for six consecutive summers of study. Thus, the four studies in which density of golden mice was greater than that of $P$. gossypinus were Smith et al. (1971) and Smith et al. (1974), both conducted in South Carolina, Shadowen (1963) in Louisiana, and Packer and Layne (1991) in Florida.

In another study in which golden mice were the numerically dominant small mammal (but for which no density estimates could be made), Miller et al. (2004) used transects of snap traps to evaluate the small mammal community in streamside management zones (SMZs) in intensively managed loblolly pine plantations located in Arkansas. O. nuttalli comprised 36.9 percent of the 1701 total captures, Blarina carolinensis (southern short-tailed shrew) comprised 28.9 percent, and 4 Peromyscus species combined comprised 21.9 percent. SMZs were dominated by hardwoods; for those $(>60 \mathrm{~m}$ ) wide, $>70$ percent of golden mice were captured in traps at the boundary between pine plantation and SMZ.

In the only example in which golden mice were more numerous than whitefooted mice, Dolan and Rose (2007), using live traps followed by pitfall traps in seasonal trapping in different-aged loblolly pine plantations in eastern Virginia, caught highly varying proportions of both species. On three 1-year-old stands, O. nuttalli was absent, but $72(\overline{\mathrm{X}}=24)$ P. leucopus were caught. Means for the other replicated stands (O.nuttalli:P. leucopus) were as follows: 8-year-old stands $=6: 0,18$-year-old stands $=4.5: 0.5$, and 24-year-old stands $=2.7: 4.6$. Commercial thinning in two of the three oldest pine stands likely added the shrubby structure to enable golden mice to persist; unthinned stands of this age have little undergrowth below the canopy. Loeb (1999) also noted that $O$. nuttalli was captured only in salvaged (regenerating) plots following tornado destruction of longleaf pine (P. palustris) stands in the Upper Coastal Plain of South Carolina. 


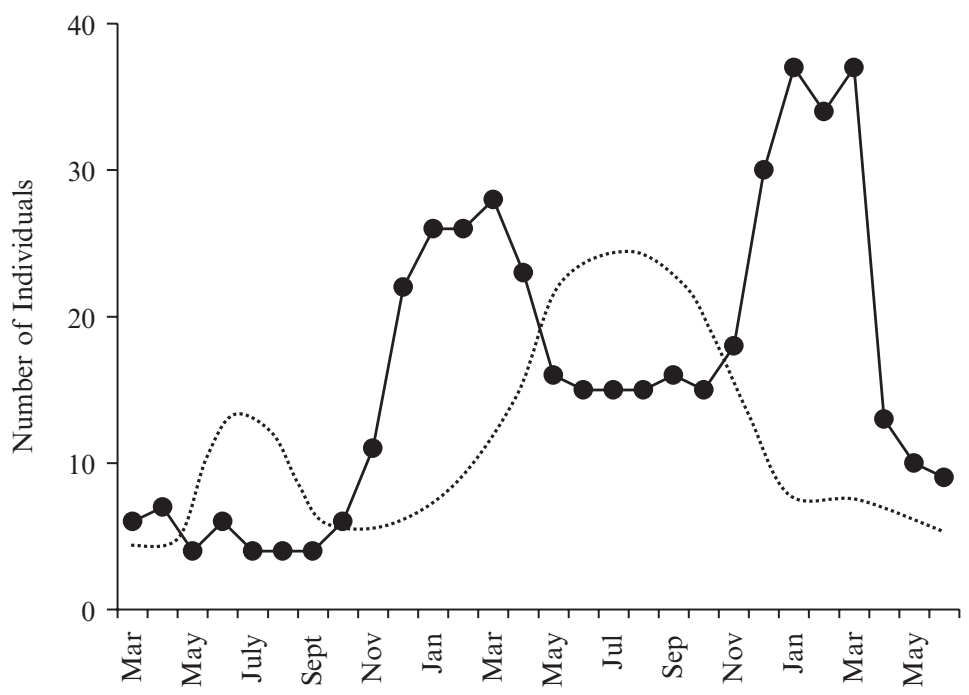

FIGURE 3.2. Patterns of abundance for populations of golden mice from the South (black dots = eastern Texas; based on McCarley 1958) and a hypothetical population from the North (dashed line). Populations from the South attain highest densities in winter/spring, whereas those from the North in summer/autumn.

Finally, information is available from two other studies conducted in Virginia, near the northern limit of distribution. Using tree-mounted nest boxes on large grids in the seasonally flooded hardwood forest in the Dismal Swamp of Virginia, Rose and Walke (1988) recorded golden mouse density of less than 2/ha. Ochrotomys was absent on 2 of the 4 grids, and, overall, P. leucopus outnumbered golden mice by $36: 9$. In a study using live traps distributed in quality habitat at 3 sites in southwestern Virginia, Wilder and Fisher (1972) caught 30 golden mice and 211 white-footed mice. No density estimate is possible, but in this study P. leucopus outnumbered $O$. nuttalli 7:1.

Figure 3.2 shows the hypothetical differences between the peak densities of northern populations, with peak densities in late autumn, compared to those of southern populations, in which peak densities sometimes are achieved in late winter or early spring.

\section{Sex Ratio}

When the sex ratio of golden mice is examined, parity is the usual result. For example, Goodpaster and Hoffmeister (1954) found 22 males and 24 females in nests during the winter. Likewise, Linzey and Linzey (1967a) recorded 105 males and 97 females in their studies of litters. Significant deviations from parity, 
however, include 20 males and 6 females $\left(\chi^{2}=7.54,1 d f, p<0.01\right)$ taken with snap traps in South Carolina (Faust et al. 1971), and 94 males and 58 females $\left(\chi^{2}=8.53,1 \mathrm{df}, p<0.001\right)$ reported by Linzey (1968) in his field study in the Great Smoky Mountains. The $\geq 50$ percent proportion of adult males every month (Linzey 1968) is suggestive of differential mortality.

\section{Age Distribution}

Frank and Layne (1992), using CMR methods in Florida, reported that only adult golden mice were present in summer, but the winter population had slightly more subadults than adults, results that support winter breeding. McCarley (1958), who presented proportions of adults:immatures for both sexes for each month of his study, reported high proportions of adults, often 100 percent, during the May-October period. The percentages of immatures were highly variable during November-April. These proportions also support winter breeding in this species. Linzey (1968) found the highest proportions of immatures in June, July, and December and mostly adults in other months.

\section{Patterns of Dispersion}

Dispersion refers to the pattern in which organisms are distributed in space, whether uniformly (as rows of trees planted in a pine plantation or pieces positioned on a chess board), randomly (no pattern), or clumped (aggregated). Due in part to their habitat requirements, golden mice usually are found in clusters, whether in dense viny thickets in forests or along forest edges. Many investigators stated that when one arboreal nest is found, others likely will be found nearby. These clusters of nests often are separated by large areas of seemingly similar habitat in which no arboreal nests or golden mice can be found (e.g., Ivey 1949, Pearson 1953). Sometimes investigators measured habitat complexity, but usually the assessments were subjective.

For example, McCarley (1958) categorized the condition of underbrush in a pine-oak upland forest in eastern Texas as dense, intermediate, or sparse. Traps and nest boxes at locations with dense vegetation had significantly $\left(\chi^{2}=26.78\right.$, $2 d f, p<0.001)$ more captures than in less vegetated trapping locations. He concluded that dispersion in $O$. nuttallii was related to, and perhaps regulated by, amounts of brushy and dense vegetation. McCarley (1958), who frequently observed more than one golden mouse in a nest box, found that ground and tree nest boxes were used equally $\left(\chi^{2}=0.96,1 d f, p>0.50\right)$. Ivey (1949:160), who found greater than 1000 nests from 1939 to 1942 in eastern Florida, reported that "golden mice appear to live in rather loosely knit communities consisting of 3-4 occupied nests. When one nest is discovered, there are likely to be others, while in large tracts of similar country it is impossible to find a single nest." This suggests 
a nonrandom distribution of groups of (perhaps related) golden mice. Nests sometimes had more than one inhabitant, including pairs, but males were never found in nests with young nor were young of two ages found together.

Pearson (1953:206), in central Florida, reported that except for one male and one female, all other resident golden mice "were clustered in a restricted area of about one acre ( $0.4 \mathrm{ha}$ ) of dense shrubby habitat on the mesic ridge." This is another example of the nonrandom dispersion of golden mice in a diverse landscape.

At ORNERP near Knoxville, golden mice showed a strong affinity for an open area at the margins of a swamp in the summer but used an area dominated by cedars and avoided the swamp in autumn. This pattern of movement suggests that areas of occupied habitat might change with changing availability of resources (Kitchings and Levy 1981). Thus, patterns of dispersion might be less static from season to season than previously believed.

In addition to residents (some caught up to 40 times), Linzey (1968) reported the presence of a small number ("3-4 each month") of transients-animals trapped once or twice. This suggests highly sedentary as well as clumped groups of residents.

The high proportion of overlapping home ranges of both sexes suggests a gregarious nature for the 19 radiocollared golden mice monitored by Morzillo et al. (2003) in southern Illinois. The home ranges of 9 of 19 mice overlapped almost completely, and nest sharing occurred among all 5 females in this group. However, no nest sharing was observed among the 4 males nor among any heterosexual groups.

Blus (1966b) found 87 hollow globular nests, mostly unoccupied, located an average of $13.1 \mathrm{~m}$ apart. However, some nests were isolated from others by distances of $>200 \mathrm{~m}$, suggesting a random distribution within a cluster of nests. Distances between two nests occupied on the same day were $42.6 \mathrm{~m}$ and $54.9 \mathrm{~m}$.

Dunaway (1955), by following paint-marked individuals during late autumn in Tennessee, found three females often living in the same nest. In yet another example of a group of golden mice living in close proximity, Eads and Brown (1953) collected five adults and six juveniles at the base of a rotten stump in a bottomland of deciduous forest dominated by sweet gum (Liquidambar styraciflua), bay (Gordonia lasianthus), oak (Quercus spp.), and holly (Ilex opaca), with dense undergrowth of cane (Arundinaria gigantea), greenbrier (Smilax spp.), and blackberry (Rubus spp.) located near Tuscaloosa, Alabama. The juveniles must have come from two or more litters, because litters of more than four are unknown in $O$. nuttalli. This finding again indicates clumped distribution. In yet another example of a group of golden mice living in close proximity, Goodpaster and Hoffmeister (1954) found multiple males and females in the same nests in Kentucky, mostly in the winter. The largest number was three of each sex from a nest on 24 November 1951.

Finally, in another study in southern Illinois, Andrews (1963) found eight golden mice clustered in "close proximity" in one drainageway of an eroded upland old field. Although absent in that drainageway, white-footed mice occupied all other drainageways. 


\section{Home Range}

Home range, as defined by Burt (1943:351), is "that area traversed by the individual animal in its normal activities of food gathering, mating, and caring for young." Home range size, often assessed by determining the enclosed area using captures at marginal locations, is more accurately estimated by using locations determined by radiotelemetry. Sometimes home range is estimated by a linear measurement, such as longest linear distance moved or the longest distance moved from a nest or trap. The term "territory," an area defended, has not been used by any investigator studying golden mice. I used the inclusive boundary strip method of Stickel (1954) to recalculate home ranges from published studies (Table 3.2).

For 39 males captured 3-40 times, the home range increased with the number of captures (Linzey 1968). For males with $\geq 9$ captures, the average home range size was 0.26 ha; females averaged 0.24 ha (Table 3.2). The largest home ranges were 0.63 ha for a male and 0.39 ha for a female. Using the average distance moved between successive captures as another index of home range, Linzey (1968) reported values of $31.4 \mathrm{~m}$ in 1964 and $59.3 \mathrm{~m}$ in 1965 , when densities were much lower. Values for females were 31.7 and $27.1 \mathrm{~m}$, respectively.

Home ranges of males ( $0.60 \mathrm{ha})$ also were similar to those of females ( $0.54 \mathrm{ha})$ for animals caught $\geq 10$ times in eastern Texas (McCarley 1958). McCarley (1958) also found that the area of home ranges was related to the number of captures; the largest home range for a female captured 29 times was 1.26 ha. Shadowen (1963) calculated the home range size for $O$. nuttalli to be 0.53 ha on a control plot (loblolly/ shortleaf pines), and 0.43 ha on a burned plot in northern Louisiana. Pruett et al. (2002), using radiotelemetry, reported a mean home range size for male $O$. nuttalli as 0.90 ha and 0.50 ha for females. The home ranges of males and females did not differ significantly in any of these three studies.

Dunaway (1955) reported mean home range size of 0.11 ha for three female golden mice captured from late October to early December in Tennessee. Using a 16.4-ha grid of live traps, Faust et al. (1971) calculated home range sizes of males (0.93 ha) and females (0.38 ha) in South Carolina, using the inclusive boundary strip method. They also determined that the average distances between successive captures were $77.6 \mathrm{~m}$ and $37.6 \mathrm{~m}$, respectively.

Some investigators believed that golden mice have small home ranges based on knowledge of their environment. For example, Goodpaster and Hoffmeister (1954:20) stated that "although we have no figures, it is firmly believed that the home range is small, and that nightly forays are made short distances from the nest. It is necessary to set traps close to occupied nests to take specimens." deRageot (1964) agreed, saying that the home range size is small because animals are trapped close to their nest sites.

Morzillo et al. (2003), using radiotelemetry to find arboreal and ground nests, determined the home ranges of golden mice in southern Illinois. Whether using minimum convex polygon (MCP) method ( 0.53 ha for males, 0.37 ha for females) 


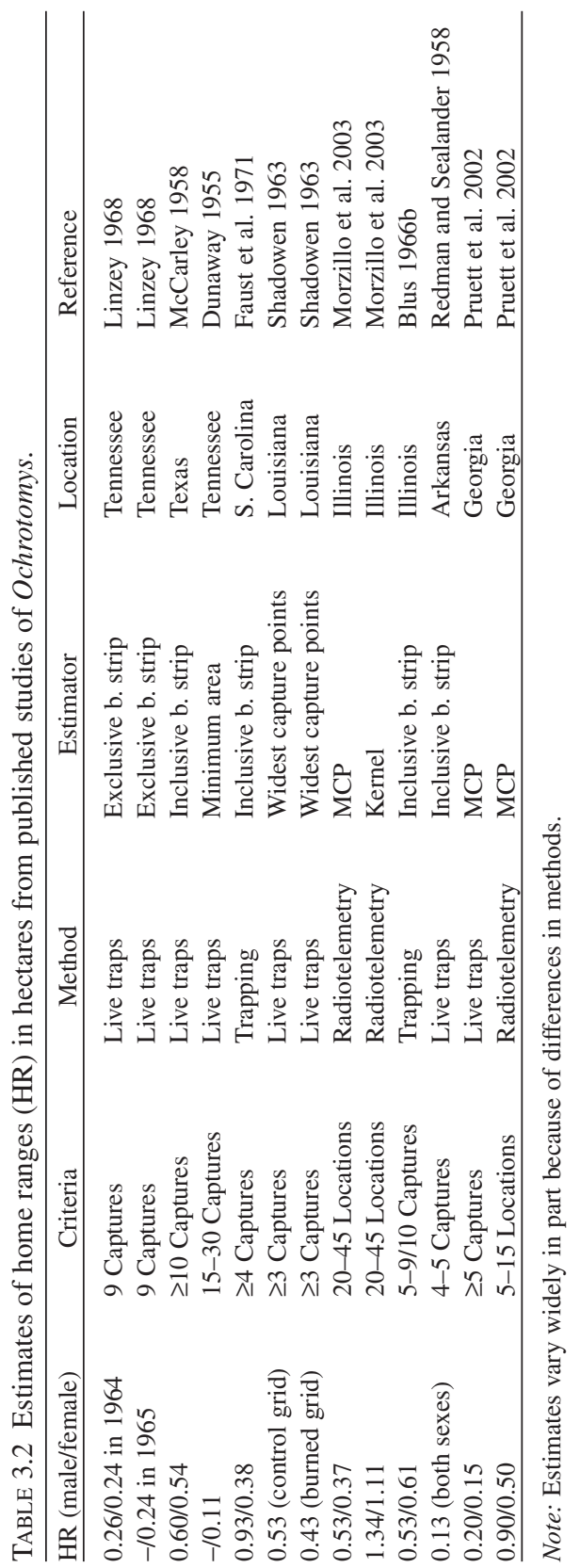


or average kernel estimate (1.34 ha and 1.11 ha, respectively), home range sizes between sexes did not differ. Nor were there differences seasonally-when the trees had leaves or not. Further, 18 of 19 radiocollared animals had overlapping home ranges, 9 of which overlapped with only 1 other golden mouse. One male-female pair shared a nest every day during observation, but another never shared nests. Among pairs, the percentage of overlap differed significantly for the MCP method but not for kernel estimates. Home range overlaps for female-female pairs were 38 percent (MCP) and 46 percent (kernel), 32-35 percent for male-female pairs, and 21 percent $(\mathrm{MCP})$ and 34 percent (kernel) for male-male pairs. The percentages of home range overlap were not different between seasons. Thus, the results of several studies support the assertion of similar or equal home range areas for males and females.

Blus (1966b), using the greatest linear distance traveled, found that males, caught 4-10 times, traveled from 42.4 to $147.2 \mathrm{~m}$ during a period of 5 months. The longest linear distance by a female, caught 15 times in March, was $60.4 \mathrm{~m}$. As with home range calculations, more captures usually translates to greater distances moved. Pearson (1953) did not calculate home ranges for golden mice in central Florida, but he did determine the distances moved from release to recapture points. Golden mice moved less widely than syntopic cotton mice, and 62 percent of recaptures of $O$. nuttalli were at distances $<38 \mathrm{~m}$, perhaps indicating a sedentary nature. Whether using area or linear measurements, the home range of a golden mouse is, as presently understood, approximately equal to the area of two-thirds of a football field.

As noted by Meserve (1977) and Christopher and Barrett (2006), investigators estimating home range in arboreal small mammals should consider not just area (length $\times$ width dimensions) but also elevation (height). The realm of golden mice and other arboreal small mammals really is three dimensional.

\section{Longevity}

Most species of small mammal have short life spans, measured in weeks or months rather than years. For populations in temperate (northern) locations, autumn-born young usually live longer than spring-born young, but the pattern of longevity is less clear for southern populations of golden mice that breed in the winter. Survival rates of small mammals usually are higher in winter than in other seasons, probably because breeding is suspended. In natural populations, only a tiny proportion (1-3 percent) of small mammals, including golden mice, live long enough to see another season of their birth. It would be interesting to learn whether winter-born cohorts of golden mice in southern populations have different life spans than autumn-born cohorts in northern populations.

During his 28-month live trapping study in the Great Smoky Mountains, Linzey (1968) recaptured many golden mice multiple times. Nineteen mice lived $\geq 5$ months, 10 mice lived $\geq 8$ months, and 2 mice lived for one full year. 
McCarley (1958) stated (but presented no data in support) that adult male golden mice had slightly longer life spans than females in eastern Texas. On one plot, 38 adults had mean minimum life spans of 6.8 months and 39 immatures averaged 6.0 months; on another plot, the values were 6.5 months and 3.1 months, respectively. McCarley (1958) estimated that 15 percent of animals lived 6 months or more, which seems to be a fairly high percentage for a small mammal. The longest field life he observed for a golden mouse was 19 months.

Pearson (1953), working in a mesic evergreen forest of central Florida, found that 6 of 10 resident golden mice lived longer than 3 months after reaching adulthood, and one lived nearly 2.5 years. In loblolly/shortleaf pine forests of northern Louisiana, Shadowen (1963) reported that one golden mouse lived nearly 10 months and six others lived 6 months after their initial captures.

\section{Population Genetics}

Little is known regarding the population genetics or metapopulation dynamics of golden mice. However, basic information is known about their chromosomes, including that their karyotypes show no variation in gross morphology of the chromosomes (Engstrom and Bickham 1982, Patton and Hsu 1967). O. nuttalli has a diploid number of 52 chromosomes, including 3 pairs of subtelocentrics, 8 pairs of metacentrics, and 14 pairs of acrocentrics of various sizes. The Y-chromosome is a small acrocentric, indistinguishable from the smallest acrocentric autosome. The $\mathrm{X}$-chromosome is slightly smaller than the largest subtelocentric autosome, and its short arm is slightly longer than that of the largest subtelocentric autosome. All members of the genus Peromyscus have 48 chromosomes (Patton and Hsu 1967). Engstrom and Bickham (1982), using G- and C-banding techniques, determined that chromosomes 1 and 13 of Ochrotomys, which do not seem to be shared with peromyscines, appear to be homologous to chromosomes 1 and 10 of Sigmodon hispidus, proposed as their closest relative.

A phylogeographic study of the golden mouse using molecular methods is needed, one that should include its former congeners, P. gossypinus, P. polionotus, P. leucopus, and S. hispidus. Additional future opportunities for research on the golden mouse are noted by Barrett and Feldhamer (Chapter 12 of this volume).

\section{Conclusions}

Because $O$. nuttalli often is studied as a secondary rather than a focal species, only a few studies have evaluated its major life-history parameters. Nevertheless, the available information summarized in this chapter provides some tantalizing possibilities and opportunities for further study. For example, some southern populations of golden mice have deviated from the usual spring-autumn breeding season by sometimes breeding primarily during the cooler months and attaining highest 
densities in late winter or early spring. The frequency and adaptive value of this strategy remain to be determined, and several important research questions (genetic, ecological, physiological, and behavioral) relate to these southern populations. Compared to its close relatives in the genus Peromyscus, golden mice have small litter sizes, indicative of relatively longer lives than its former congeners if Lack's (1966) hypothesis that rates of natality have evolved to compensate for rates of mortality is correct. An indication of relatively long life spans also supports this contention of higher rates of survival than for other similar arboreal small mammals living in the same habitat. That golden mice often live in clusters of nests separated from other groups by unoccupied suitable habitat suggests a high degree of relatedness among individuals. Home ranges often are small and are similar between the sexes, perhaps indicating high levels of tolerance for neighbors, which might be relatives. Genetic studies would answer many of these questions.

One of the challenges when studying golden mice is that their specialized habitats of dense understory thickets of tangled vines in a forested matrix often disappear as secondary succession proceeds. Thus, the brushy habitat provided by $8-10$-year-old pine trees disappears quickly as the trees grow taller, thereby thinning the volume below the canopy. The same is true, probably at a slower rate, for deciduous forests. Consequently, what is good golden mouse habitat this year might not support a population in 3 or 5 years. Old fields giving way to secondary succession by the Eastern red cedar (Juniperus virginiana) might provide the greatest promise as suitable habitat for sustaining populations of golden mice for long-term investigations. Because they exhibit less self-thinning than other conifers, red cedars, as they grow, continue to provide the three-dimensional habitat seemingly required by golden mice. Hopefully, the National Science Foundation will recognize this opportunity by funding a collaborative LTREB grant. In all, much remains to be learned about the population biology of the golden mouse.

\section{Literature Cited}

Andrews, G.D. 1963. The golden mouse in southern Illinois. Natural History Miscellanea 179:1-3.

Blus, L.J. 1966a. Relationship between litter size and latitude in the golden mouse. Journal of Mammalogy 47:546-547.

Blus, L.J. 1966b. Some aspects of golden mouse ecology in southern Illinois. Transactions of the Illinois Academy of Science 59:334-341.

Burt, W.H. 1943. Territory and home range concepts as applied to mammals. Journal of Mammalogy 24:346-352.

Christopher, C.C., and G.W. Barrett. 2006. Coexistence of white-footed mice (Peromyscus leucopus) and golden mice (Ochrotomys nuttalli) in a southeastern forest. Journal of Mammalogy 8:102-107.

deRageot, R.H. 1964. The golden mouse. Virginia Wildlife 25:10-11. 
Dolan, J.D., and R.K. Rose. 2007. Depauperate small mammal communities in managed pine plantions in eastern Virginia. Journal of the Virginia Academy of Science In press.

Dueser, R.D., and H.H. Shugart, Jr. 1979. Niche pattern in a forest-floor smallmammal fauna. Ecology 60:108-118.

Dunaway, P.B. 1955. Late fall home ranges of three golden mice, Peromyscus nuttalli. Journal of Mammalogy 36:297-298.

Eads, J.H., and J.S. Brown. 1953. Studies on the golden mouse, Peromyscus nuttalli aureolus in Alabama. Journal of the Alabama Academy of Science 25:25-26.

Engstrom, M.D., and J.W. Bickham. 1982. Chromosome banding and phylogenetics of the golden mouse, Ochrotomys nuttalli. Genetica 59:119-126.

Faust, B.F., M.H. Smith, and W.B. Wray. 1971. Distances moved by small mammals as an apparent function of grid size. Acta Theriologica 16:161-177.

Feldhamer, G.A., and K.A. Maycroft. 1992. Unequal capture response of sympatric golden mice and white-footed mice. American Midland Naturalist 128:407-410.

Feldhamer, G.A., and C.R. Paine. 1987. Distribution and relative abundance of the golden mouse (Ochrotomys nuttalli) in Illinois. Transactions of the Illinois Academy of Science 80:213-220.

Frank, P.A., and J.N. Layne. 1992. Nests and daytime refugia of cotton mice (Peromyscus gossypinus) and golden mice (Ochrotomys nuttalli) in south-central Florida. American Midland Naturalist 127:21-30.

Goodpaster, W.W., and D.F. Hoffmeister. 1954. Life history of the golden mouse, Peromyscus nuttalli, in Kentucky. Journal of Mammalogy 35:16-27.

Ivey, R.D. 1949. Life history notes on three mice from the Florida east coast. Journal of Mammalogy 30:157-162.

Kitchings, J.T., and D.J. Levy. 1981. Habitat patterns in a small mammal community. Journal of Mammalogy 62:814-820.

Lack, D.L. 1966. Population studies of birds. Oxford University Press, Oxford, United Kingdom.

Layne, J.N. 1960. The growth and development of young golden mice, Ochrotomys nuttalli. Quarterly Journal of the Florida Academy of Sciences 23:36-58.

Linzey, D.W. 1968. An ecological study of the golden mouse, Ochrotomys nuttalli, in the Great Smoky Mountains National Park. American Midland Naturalist 79:320-345.

Linzey, D.W., and A.V. Linzey. 1967a. Growth and development of the golden mouse, Ochrotomys nuttalli nuttalli. Journal of Mammalogy 48:445-458.

Linzey, D.W., and A.V. Linzey. 1967b. Maturational and seasonal molts of the golden mouse, Ochrotomys nuttalli. Journal of Mammalogy 48:236-241.

Loeb, S.C. 1999. Responses of small mammals to coarse woody debris in a southeastern pine forest. Journal of Mammalogy 80:460-471. 
Lord, R.D., Jr. 1960. Litter size and latitude in North American mammals. American Midland Naturalist 64:488-499.

McCarley, W.H. 1958. Ecology, behavior and population dynamics of Peromyscus nuttalli in eastern Texas. Texas Journal of Science 10:147-171.

Mengak, M.T., and D.C. Guynn, Jr. 2003. Small mammal microhabitat use on young loblolly pine regeneration areas. Forest Ecology and Management 173:309-317.

Meserve, P.L. 1977. Three-dimensional home ranges of cricetid rodents. Journal of Mammalogy 58:549-558.

Miller, D.A., R.E. Thill, M.A. Melchoirs, T.B. Wigley, and P.A. Tappe. 2004. Small mammal communities of streamside management zones in intensively managed pine forests of Arkansas. Forest Ecology and Management 203:381-393.

Morzillo, A.T., G.A. Feldhamer, and M.C. Nicholson. 2003. Home range and nest use of the golden mouse (Ochrotomys nuttalli) in southern Illinois. Journal of Mammalogy 84:553-560.

Packer, W.C., and J.N. Layne. 1991. Foraging site preferences and relative arboreality of small rodents in Florida. American Midland Naturalist 125:187-194.

Patton, J.L., and T.C. Hsu. 1967. Chromosomes of the golden mouse, Peromyscus nuttalli Harlan. Journal of Mammalogy 48:637-639.

Pearson, P.G. 1953. A field study of Peromyscus populations in Gulf Hammock, Florida. Ecology 34:199-207.

Perry, R.W., and R.E. Thill. 2005. Small mammal responses to pine regeneration treatments in the Ouachita Mountains of Arkansas and Oklahoma, USA. Forest Ecology and Management 219:81-94.

Pruett, A.L., C.C. Christopher, and G.W. Barrett. 2002. Effects of a forested riparian peninsula on mean home range size of the golden mouse (Ochrotomys nuttall) and the white-footed mouse (Peromyscus leucopus). Georgia Journal of Science 60:201-208.

Redman, J.P., and J.A. Sealander. 1958. Home ranges of deer mice in southern Arkansas. Journal of Mammalogy 39:390-395.

Rose, R.K., and J.W. Walke. 1988. Seasonal use of nest boxes by Peromyscus and Ochrotomys in the Dismal Swamp of Virginia. American Midland Naturalist 120:258-267.

Schmid-Holmes, S., and L.C. Drickamer. 2001. Impact of forest patch characteristics on small mammal communities: A multivariate approach. Biological Conservation 99:293-305.

Seagle, S.W. 1985a. Patterns of small mammal microhabitat utilization in cedar glade and deciduous forest habitats. Journal of Mammalogy 66:22-35.

Seagle, S.W. 1985b. Competition and coexistence of small mammals in an east Tennessee pine plantation. American Midland Naturalist 114:272-282.

Shadowen, H.E. 1963. A live trap study of small mammals in Louisiana. Journal of Mammalogy 44:103-108. 
Smith, M.H., R. Blessing, J.G. Chelton, J.B. Gentry, F.B. Golley, and J.T. McGinnis. 1971. Determining density for small mammal populations using grid and assessment lines. Acta Theriologica 16:105-125.

Smith, M.H., J.B. Gentry, and J. Pinder. 1974. Annual fluctuations in small mammal population in an eastern hardwood forest. Journal of Mammalogy 55:231-234.

Stickel, L.F. 1954. A comparison of certain methods of measuring home ranges of small mammals. Journal of Mammalogy 35:1-15.

Wallace, J.T. 1969. Some notes on the growth, development and distribution of Ochrotomys nuttalli (Harlan) in Kentucky. Transactions of the Kentucky Academy of Science 30:45-52.

Wilder, C.D., Jr., and R.D. Fisher. 1972. Occurrence of the golden mouse in southwestern Virginia. Chesapeake Science 13:326-327. 